\title{
Models of Structuring Peace and Gandhi in Modern Democratic System
}

\section{Sumit Narula*}

Amity School of Communication, Amity University, Noida, India

\section{Models of Structuring Peace and Gandhi in Modern Democratic System}

The concept of world peace has been fascinating indeed. Gandhi realised that if the embodied human spirit was to progress, muffled as it was by selfish desire, man must be free, full of dignity and earnest about his own advance. "There has been no greater advocate of one humanity, one world and no stronger opponent of violence and war than Gandhi, for, his faith in no-violence was absolute and he believed that peaceful means alone could lead to peaceful ends [1]" 'While world peace is undoubtedly one of the most universal and significant of human ideals, Gandhi has described is as 'one of the few positive symbols having meaning for the whole of humanity' The present world is beset with problems like international terrorism, arms race, civil wars and ethnic and religious problems. Though cold war is over, there are smaller conflicts between and among nations. These regional conflicts have disturbed international peace, attempts for disarmaments, confidence building measure etc. The twentieth century was by far the bloodiest and most destructive century in the history of the human race. According to UN statistics, there were only twenty eight days in this entire century of genocide and destruction without a war of some kind, in some part of the globe.

Mahatma Gandhi has always spoken about structuring peace throughout his life. Gandhi showed the world not only the goal of peace but the supreme method of achieving world peace. George C Marshall writes, "In his devotion to structuring peace and tolerance of the brotherhood the Mahatma was one of those rare spokesman for the conscience of all mankind [2]." Structuring peace and tolerance, for Gandhi, were the supreme means for the realisation of Truth and Love which were identical to the Ultimate End of man. Gandhi developed his world-view against the background of a world of violence. Paying tribute to Mahatma Gandhi on his $75^{\text {th }}$ birthday, Albert Einstein wrote: "Generations to come, it may well be, will scarcely believe that such a one as this ever in flesh and blood walked upon this earth [3]". Gandhi today has become a universal symbol more than anything else of the supreme principles of truth, love, non-violence, justice and human brotherhood. It is precisely a desire to bridge this gap between the 'ideal' and the 'real' that attracts researchers to the peace programme.

\section{Structuring Peace Through Coercive Power}

The first peace paradigm, power politics or 'realpolitik', is the traditionally dominant framework in the field of international relations. This paradigm, grounded in classic works such as Thucydides' History of the Peloponnesian War as well as in a more recent body of political theory. There is a very popular saying that "Villains don't fall from the skies, neither do they pop out of the ground like evil spirits. They must be seen as symptoms of society and therefore every citizen is responsible for their existence [4]". Violence arises inevitably from human competitiveness and covetousness; peace is secured through the forceful imposition of order.

\section{Structuring Peace Through Mutual Understanding}

The second paradigm, conflict resolution, offers a highly pragmatic approach to peace through the development and refinement of skills for analyzing conflicts and responding to them with effective strategies of communication and negotiation. According to this paradigm, conflict is a natural at all levels of human interaction and organisation, from inter-personal to the inter-ethnic and international. To manage and resolve conflicts effectively, we must become aware of our attitudes towards conflict and our habitual conflict management style so as to attain greater freedom to define our responses in a proactive and coordinated way. Such awareness increases our chances of achieving "win-win" rather than "win-lose" or "lose-lose" solutions. We learn to understand and work with our own emotions, to generate openness to more authentic communication, and to control processes that might otherwise lead to escalation.

It would seem to be a reasonable assumption that Gandhi's wellpublicised examples of non-violence resistance and the voluminous writings on his technique at least set the tone for the later development and phenomenal growth of conflict resolution literature in the guise of modern problem-solving and win-win approaches leading to integrative conflict resolution.

\section{Structuring International Peace Through Power of Law}

The third approach to peace explored by the class is the world order paradigm. This paradigm, which views the 'order' created by practices of power politics as a form of disorder, proposes that sustained cooperation among states and other significant factors, such as nongovernmental organisations and inter-governmental organisations is both possible and necessary. Co-operation is possible because human nature contains the potential for both selfishness and altruism.

To affirm that principled co-operation is possible, the world order paradigm emphasizes human choice and intentionally while asserting that nation-states do not have a monopoly on power to shape global politics. The nation-state is not the only forum for political activity and accountability, and the national interest is not the exclusive criterion for desirable behaviour. In an age of globalisation, politics involves a complex interplay of global and national as well as local loyalties, values and interests. Modern communications and transportation technologies have empowered citizens to form transportation networks for advancing concerns linked to peace, human rights, ecology and development.

${ }^{*}$ Corresponding author: Sumit Narula, Amity School of Communication, Amity University, Noida, India,Tel: 9560452625; E-mail: suminarula@gmail.com

Received April 06, 2012; Accepted April 06, 2012; Published April 08, 2012

Citation: Narula S (2012) Models of Structuring Peace and Gandhi in Modern Democratic System. J Mass Commun Journalism 2:e117. doi:10.4172/21657912.1000e117

Copyright: () 2012 Narula S. This is an open-access article distributed under the terms of the Creative Commons Attribution License, which permits unrestricted use, distribution, and reproduction in any medium, provided the original author and source are credited. 


\section{Structuring Peace Through Mediation}

The final approach to peacemaking investigated in the peace paradigms course is the transformation paradigm, a paradigm that focuses on the centrality of education, cultural change and spirituality in all genuine attempts to make peace a reality in daily life. From the standpoint of the transformation paradigm, peacemaking is not only an effort to end war, remove structural violence, or establish the presence of external value conditions. It is also a profoundly internal process, in which the transformation is individual becomes a metaphor for an instrument of broader changes. Peaceful behaviour is a learned behaviour, and each individual is a potential and needed contributor to a culture of peace.

Mahatma Gandhi takes real democracy to be that admits governmental interference all the minimum, which has peace at the maximum and all progress on the basis of equality. It is possible only when non-violence is imparted the supreme status in practice as well as in principle and at social as well as individual plane. Only such a democracy can be successful in its real goal.

\section{Gandhian Concept of Peace and Satyagraha}

Nonviolence (ahimsa) is a way of life rather than a tactic, and, together with the search for truth (Satyagraha), makes the difference between passive submission to injustice, and an active struggle against it. This struggle excludes both physical violence and casting the opponent in the role of enemy, and hence presupposes compassion and self-criticism. The notion of welfare to all (sarvodaya) also sees peace as incompatible with exploitation or inequality of wealth. Peace is not seen as an end state, but as a continuous revolutionary process, where ends cannot be separated from means.

Satyagraha is Gandhi's technique of non-violent activism. The term has variously been translated as 'passive resistance', 'non-violent resistance', 'non-violent direct action' and even 'militant non-violence'. For Gandhi, it was not only a method of conducting conflict but it was also a way of life, living in truth. From the standpoint view of nonviolence activists, this assumption reflects the dominance of ability to hurt and therefore regard it as the exclusive possession of governments and armed militant groups.

In response, the non-violence paradigm proposes that the power of any government derives primarily from the consent of the people, and only secondarily from coercion. By consenting to any given state of affairs and operating within the framework of norms that it offers, human beings empower that order and, if its norms are dehumanising, disempowered and dehumanise themselves. In Gandhi's theory of peace, human values take great prominence.

Presently, the democratic system in operation in worldly nations is not according to Gandhian principles. We are not getting what Mahatma Gandhi ultimately cherished from democracy. If it is so, these nations could be devoid of atmosphere of non-violence and presence of fear. There could not have been corruption and divided human society. It is already emphasized that there could not have been problems pertaining to terrorism, communalism, regionalism and problems related to languages. More than this all, there could not have been observance of ethical and more degradation in public life. Such degradation is being observed constantly. The main cause after all these things remain that all activities of these nations are not non-violent. There cannot be any possibility of violence while there is gandhism in democracy. Mahatma Gandhi has once said that, 'Democracy and violence can never be mutual'.

\section{Modern system of Government and Gandhian Peace}

The question arises before us as to how to guide modern system of government, especially democracy, towards Gandhian way, which undoubtedly has non-violence as its basic root. Then, it is to be made and quotable towards equal development of all citizens. This democracy must be such that "it should not warrant power of punishment "[5]. He was not against reason or rationality at all but his was a critique of the domineering and hegemonic nature of modern instrumental rationality. This modern hegemonic rationality has captured different aspects of modern life-style and Gandhi tried to criticise each of these one by one.

Modern machines and the kind of the functions these machines perform have developed another problematic feature of modern society, that is, universalism. Universalism is a trend where all people are thinking in a similar direction. All are living a similar kind of lifestyle and they cannot keep their individuality, their uniqueness alive as it will not be welcomed. Universalism not only kills an individual's initiative to do something new in a different manner, but it also enhances the tendency of centralisation and hegemony. And modern bureaucratic structures and political institutions like Parliament and State are some of the means which zealously try to be universal. For Gandhi, universalism is a violent philosophy perpetuated by the capitalists across the globe.

Gandhi was against any form of centralised tendency or universalism. He raised his voice for Swaraj and swadeshi. For Gandhi, the highly centralised and bureaucratic modern state represents violence in a concentrated and organised form. The individual has a soul, but as the state is a soulless machine, it can never be weaned away from violence to which it owns its very existence. Accordingly, modern states are structured in such a way that they encourage exploitation and violence discouraging the importance of the individual and his/ her local recognitions. That is why Gandhi used to say that the state dehumanised its citizens in more or less the same way as the medical, legal and other modern institutions. It had a vested institutional interest in monopolising all initiative and fostering a state-centered political culture. The more its citizens became 'addicted' to it and the more they felt helpless without it, the safer it felt. Accordingly, it systematically nurtured the illusion that the problems of society were too complex and intractable to be solved by ordinary citizens acting individually or collectively, and was best left to the state and its official agencies. It felt threatened by active and independent-minded citizens determined to participate in the conduct of their affairs and worried lest they should be morally compromised by what it did in their name [6]. It therefore, denied them access to vital information and opportunities for political participation, and discouraged independent and vibrant local communities capable of challenging its decision.

A well-known Gandhian philosopher, Gopinath Dhawan, writes in this context that Gandhi sincerely believed that the state represented an organisation based on force. It manifested its coercive power through compulsion and exploitation of individuals in society. Gandhi decried any action of individuals in the state which was immoral, since in 
Citation: Narula S (2012) Models of Structuring Peace and Gandhi in Modern Democratic System. J Mass Commun Journalism 2:e117. doi:10.4172/2165-7912.1000e117

Page 3 of 3

his scheme of thinking every action was judged by the touchstone of ethical priority. He argued that "no action which is not voluntary can be called moral... if we want to call an action moral, it should have been done consciously and as a matter of duty [7]".

Gandhi wanted to persuade the politicians to accept the institution of state and power not as an end in itself but as an instrument. Accordingly, the state shall be regarded as a servant of the society and all its deeds should be guided by the sense of duty. Gandhi looked upon an increase in the power of the state with the greatest fear, because although while apparently doing well by minimising exploitation, it does the greatest harm to mankind destroying individuality, which lies at the root of all progress.

Destroying individuality means exploitation leading to violence. Therefore, to avoid violence and to ensure maximum flowering of the human personality, decentralisation of political power must become an end of a progressive and welfare-oriented society. For Gandhi, politics should be treated only as means. The state should try to decentralise its power. As much power a state will disperse, that much non-violent it will become. According to Gandhi, rights are not to be claimed but these are a kind of social value through which the individual will move on to the path of self-realisation. And in Gandhi's account, if an individual is embedded with moral and human values, then automatically s/he will achieve rights to actualise his/her humanitarian deeds. Then the importance of the institution of the state as a law providing institution would automatically wither away. There is then a state of enlightened anarchy. In such a state sovereignty vests in everyone who is his own ruler. He governs himself in a manner that he represents the freedom of his neighbours and in all such activity there is no political power because there is no state. But a single trait of all these features is not found in the modern state.

In Ramrajya there is not any notion of state at all. Swaraj, the second best option, is to be obtained by educating the masses to a sense of their capacity to regulate and control authority. This Swaraj would be of each and every individual, whosoever is residing there inside the state by accepting the importance of differences of caste, community, society and the different cultural and historical backgrounds. Because these are some factors through which an individual gets his/her recognition. Thus, Gandhi criticised the universalistic tendency of modernism. As per Ronald J. Terchek, Gandhi sees the universalising impulse of modernity as inhospitable of plurality. In its search for general rules, modern reason seeks to identify relevant verities and discards superfluous one what remains outside of the realm of the verifiable is unimportant to the enterprise replicated with the same result by distant, neutral strangers.

\section{Conclusion}

Polity must be fearless, full of equality, providing protection to all eternal values and only then it can be pro-people. Gandhian principle of non-violence is very much significant in modern system of government from this point of view. This significance is likely to be of permanent nature perpetually.

\section{References}

1. Collected Works of Mahatma Gandhi (1958-83) Hundred Volumes. New Delhi Publications Division, Ministry of Information and Broadcasting, Government of India.

2. Gandhi MK (1927-1929) Story of My Experiments With Truth, Vol. I (Tr. By Mahadev Desai from Gujarati) and Vo1. II Tr. (By Mahadev Desai and Pyarelal Nair (sic) from Gujarati) Ahmedabad: Navajivan Press.

3. Gandhi MK (1931) Hind Swaraj, or Indian Home Rule. Navajivan Press Ahmedabad.

4. Gandhi MK (1930) Ethical Religion: Neethi Dharma, Tr. by A. Rama Iyer from Hindi (Madras: S. Ganesan).

5. Gandhi MK (1972) Satyagraha in South Africa. Navajivan, Ahmedabad.

6. Gandhi MK (1945) Constructive Programme: Its Meaning and Place. Navajivan Ahmedabad.

7. Gandhi MK (1998) The Bhagvadgita. Orient Paperbacks, Delhi. 